\title{
Immobilized Stearic Acid as a New Sorbent for On-Line Preconcentration and Determination of Lead by Flow Injection Flame Atomic Absorption Spectrometry
}

\author{
Shayessteh Dadfarnia, * Ali Mohammed Haji Shabani and Zahra Dehghani \\ Department of Chemistry, Yazd University, Yazd, Iran
}

\begin{abstract}
O presente estudo examina a possibilidade de imobilização do ácido esteárico em naftaleno microcristalino para a preparação de microcoluna e avalia seu potencial para adsorção e préconcentração de quantidades traço de íons metálicos. Esse sorvente apresentou alta afinidade para chumbo. Conseqüentemente, foi elaborada uma rápida estratégia de pré-concentração empregando sistema de injeção em fluxo para determinação de chumbo por Espectrometria de Absorção Atômica com chama. A pré-concentração foi baseada no acúmulo do analito na microcoluna de ácido esteárico imobilizado e subseqüente eluição por injeção de pequeno volume de solução de ácido nítrico $1 \mathrm{~mol} \mathrm{~L}^{-1}(250 \mu \mathrm{L})$. Um volume de amostra de $20 \mathrm{~mL}$ resultou em um fator de préconcentração de 84 vezes e o desvio padrão relativo para soluções contendo 40 e $200 \mu \mathrm{g} \mathrm{L}^{-1}$ foi 5,1 e $1,2 \%$, respectivamente. O procedimento foi aplicado para água de torneira, de rio e de mar, suco de maçã, folha de beterraba, urina e aço inoxidável certificado. A exatidão foi comprovada por experimentos de recuperação, por Espectrometria de Absorção Atômica com Forno de Grafite e análise de um material de referência certificado composto por aço inoxidável.
\end{abstract}

The present study examines the possibility of immobilization of stearic acid on microcrystalline naphthalene for preparation of microcolumn and evaluation of its potential for adsorption and preconcentration of trace amounts of metal ions. It was found that this sorbent has high affinity for lead. Consequently, a rapid on-line preconcentration technique for the determination of lead by Flow Injection Flame Atomic Absorption Spectrometry had been devised. Preconcentration was based on accumulation of analyte on immobilized stearic acid microcolumn and subsequent elution by injection of a small volume of nitric acid $(250 \mu \mathrm{L}$ of 1 mol $\left.\mathrm{L}^{-1}\right)$. A sample volume of $20 \mathrm{~mL}$ resulted in a preconcentration factor of 84 , and relative standard deviations for solutions containing 40 and $200 \mu \mathrm{g} \mathrm{L}^{-1}$ were 5.1 and $1.2 \%$, respectively. The procedure was applied to tap water, river water, sea water, apple juice, beet leaf, urine, and certified stainless steel. The accuracy was proved by performing recovery experiments, Graphite Furnace Atomic Absorption Spectrometry measurements, and analysis of a stainless steel certified reference material.

Keywords: lead determination, immobilized stearic acid, on-line preconcentration, flow injection

\section{Introduction}

Because of toxic effects of lead on animals and human, ${ }^{1,2}$ monitoring of lead in the environmental samples is of major importance. Lead is still emitted in considerable amounts to the biosphere owing to its increased industrial use and its application as a fossil fuel additive. ${ }^{3,4}$ Thus, there is an on-going need for determination of lead at trace level because of its extensive distribution and high toxicity. Flame Atomic Absorption Spectrometry is, in principle, a suitable technique as it is

\footnotetext{
* e-mail: sdadfarnia@yazduni.ac.ir
}

rapid, simple and inexpensive; however it lacks the sensitivity necessary for determination at the $\mu \mathrm{g} \mathrm{L}^{-1}$ level. In addition, high concentration of matrix components (including the acid used for sample dissolution or digestion) may cause inaccuracies in a method, which is based on external calibration with dilute aqueous standards. Thus, a preliminary preconcentration and/or separation is needed to improve the detection limit and selectivity for the determination of lead by FAAS.

Several preconcentration techniques such as liquidliquid extraction, evaporation, sorption and chelating ion exchange have been used for trace enrichment and separation of lead. ${ }^{5-8}$ However, these manual batch 
procedures are labor, time, and reagent consuming and required large volume of sample.

Flow Injection (FI) separation and preconcentration techniques have proved to be effective for enhancement of sensitivity of Atomic Spectrometry. ${ }^{9}$ Since its introduction, Flow Injection Analysis (FIA) has attracted increasing attention because of its high precision, high sampling rate and the possibility for on-line sample pretreatment. For determination of lead utilizing flame atomic absorption different on-line microcolumn enrichment system has been developed and includes basic alumina; ${ }^{10}$ retention of lead complexes of diethyl ammonium diethyldithiocarbomate (DDDC),${ }^{11}$ ammonium diethyldithiophosphate (DDPA), ${ }^{12}$ diethyldithiocarbamate (DDTC), ${ }^{13}$ and dithizone ${ }^{14}$ on $\mathrm{C}_{18}$ bonded silica; fibrous alumina ${ }^{15}$ adsorption of pyrrolidinedithiocarbamate (APDC) complex of lead on activated carbon, ${ }^{16}$ or PTFE; $;{ }^{17}$ crown ether immobilized on XAD-7; ${ }^{18}$ macrocycle immobilized on silica gel ${ }^{19}$ retention of lead complexes of DDTC on chromosorb $102,{ }^{20}$ diethyldithiophosphate (DDTP) on $\mathrm{C}_{18}$-silica, activated carbon and polyurethane; ${ }^{21}$ Amberlite XAD-2 modified with 2-(2-benzothiazolylazo)2-p-cresol (BTAC);22 polyurethane foam loaded with BTAC $;{ }^{23}$ natural adsorbent such as vermicompost and humic acid. ${ }^{24}$ The figures of merit of the above mentioned chemistries together with the result of this work are summarized in Table 1.

Stearic acid (also called octadecanoic acid) is nature's most common long chain fatty acid, derived from animal and vegetable fats. It is widely used as a lubricant and as an additive in industrial preparation. It is used in the manufacture of metallic stearates, pharmaceuticals, soaps, cosmetics, and food packaging. It is also used as a softener, accelerator activator, and dispersing agent in rubbers. ${ }^{25,26}$

However, despite its widespread use in industry, its application in analytical chemistry is spare. It has been used as a cooperative carrier in the transport and extraction of metal ions, ${ }^{27,28}$ but its use in solid phase extraction is

Table 1. Procedures for on-line preconcentration and determination of lead by FAAS ${ }^{\text {a }}$

\begin{tabular}{|c|c|c|c|c|c|c|c|c|c|c|}
\hline Sample & Sorbent & $\begin{array}{l}\text { Chlating Agent } \\
\text { added }\end{array}$ & Eluent & $\mathrm{pH}$ range & $\begin{array}{c}\mathrm{LOD} \\
\left(\mu \mathrm{g} \mathrm{L}^{-1}\right)\end{array}$ & $\mathrm{EF}$ & R.S.D\% & $\begin{array}{l}\text { Linear } \\
\text { range } \\
\left(\mu \mathrm{g} \mathrm{L}^{-1}\right)\end{array}$ & 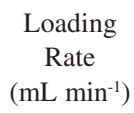 & Ref. \\
\hline Water samples & Basic $\mathrm{Al}_{2} \mathrm{O}_{3}$ & None & $\mathrm{HNO}_{3}$ & $4.8-6.3$ & 0.36 & - & $1.4-12$ & $0-100$ & 5 & 10 \\
\hline Natural water & $\mathrm{C}_{18}$ bonded silica & DDDC & $\mathrm{EtOH}^{3}$ & - & 3 & 20 & 1.0 & - & 3.3 & 11 \\
\hline Water samples & Fibrous $\mathrm{Al}_{2} \mathrm{O}_{3}$ & None & $\mathrm{HNO}_{3}$ & $\mathrm{pH}>7$ & 0.7 & - & 4.9 & $2.5-100$ & 4.5 & 15 \\
\hline $\begin{array}{l}\text { Environmental } \\
\text { sample }\end{array}$ & $\mathrm{C}_{18}$ bonded silica & DDPA & $\mathrm{MeOH}$ & $1-3$ & 10 & 26 & - & - & 8.7 & 12 \\
\hline $\begin{array}{l}\text { Mineral and } \\
\text { skim milk }\end{array}$ & Actived carbon & APDC & MIBK & - & 10 & 50 & 2.3 & $15-400$ & - & 16 \\
\hline Soil sample & $\begin{array}{l}\text { Crown Ether } \\
\text { immobilized } \\
\text { on XAD-7 }\end{array}$ & None & Oxalate & $\begin{array}{c}\mathrm{HNO}_{3} \\
\left(0.8-2 \mathrm{~mol} \mathrm{~L}^{-1}\right)\end{array}$ & $0.08 \mu \mathrm{g}$ & 22 & 4.1 & $\begin{array}{c}\text { Up to } \\
5 \mu \mathrm{g} \text { of } \mathrm{Pb}\end{array}$ & - & 18 \\
\hline $\begin{array}{l}\text { Biological and } \\
\text { vegetable sample }\end{array}$ & $\mathrm{C}_{18}$ bonded silica & DDTC & MIBK & 4.6 & 3 & 189 & 3.8 & $20-100$ & 4 & 13 \\
\hline Marine sediment & $\mathrm{C}_{18}$ bonded silica & Dithizone & $\mathrm{MeOH}$ & - & 3 & 60 & 6 & - & - & 14 \\
\hline $\begin{array}{l}\text { Environmental } \\
\text { and biological } \\
\text { samples }\end{array}$ & $\begin{array}{l}\text { Macrocycle } \\
\text { immobilized } \\
\text { on } \mathrm{C}_{18}\end{array}$ & - & EDTA & $\begin{array}{c}\mathrm{HNO}_{3} \\
\left(0.075-3 \mathrm{~mol} \mathrm{~L}^{-1}\right)\end{array}$ & 5 & 52 & 19 & - & 3.9 & 19 \\
\hline Soil and water & Chromosorb 102 & DDTC & $\mathrm{EtOH}$ & $8-10$ & 2 & 25.4 & 4 & $50-600$ & 2.2 & 20 \\
\hline - & $\mathrm{C}_{18}$-Silica & DDTP & $\mathrm{EtOH}$ & $\mathrm{HCl}$ & 0.3 & 166 & 5 & $1-10$ & 2 & 21 \\
\hline- & Actived carbon & DDTP & $\mathrm{EtOH}$ & $\left(1 \mathrm{~mol} \mathrm{~L}^{-1}\right)$ & 3 & 23 & 4.3 & $10-100$ & 4 & 21 \\
\hline- & Polyurethane & DDTP & $\mathrm{EtOH}$ & & 1.2 & 55 & 5 & $1-25$ & 2 & 21 \\
\hline $\begin{array}{l}\text { Biological } \\
\text { samples }\end{array}$ & $\begin{array}{l}\text { XAD-2 modified } \\
\text { with BTAC }\end{array}$ & None & $\mathrm{HCl}$ & $6.5-8.5$ & 3.7 & 27 & $4.4-2.3$ & $3.7-300$ & 2.25 & 22 \\
\hline $\begin{array}{l}\text { Sea food and } \\
\text { biological } \\
\text { samples }\end{array}$ & Polyurethane & None & $\mathrm{HCl}$ & $7-7.5$ & 1 & 26 & $6-0.7$ & $10-500$ & 7 & 23 \\
\hline $\begin{array}{l}\text { Water sediment } \\
\text { sand fish tissue }\end{array}$ & $\begin{array}{l}\text { PTFE } \\
\text { loaded with } \\
\text { BTAC }\end{array}$ & APDC & MIBK & $1.4-3.2$ & 0.8 & 330 & 2.6 & $1.6-100$ & 13 & 17 \\
\hline $\begin{array}{l}\text { Mineral water } \\
\text { and fruit juice }\end{array}$ & $\begin{array}{l}\text { Vermicompost } \\
\text { Humic acid }\end{array}$ & $\begin{array}{l}\text { None } \\
\text { None }\end{array}$ & $\begin{array}{l}\mathrm{HNO}_{3} \\
\mathrm{HNO}_{3}\end{array}$ & 6.5 & $\begin{array}{c}8.8 \\
12.1\end{array}$ & $\begin{array}{l}62 \\
83\end{array}$ & $\begin{array}{l}<6 \\
<5\end{array}$ & $\begin{array}{l}29.4-2000 \\
40.2-2000\end{array}$ & 44 & 24 \\
\hline $\begin{array}{l}\text { Water samples } \\
\text { apple juice, leaf, } \\
\text { urine and alloy }\end{array}$ & $\begin{array}{l}\text { Immobilized } \\
\text { stearic acid } \\
\text { with naphthalene }\end{array}$ & None & $\mathrm{HNO}_{3}$ & $6-8$ & 2.9 & 84 & $5.1-1.2$ & $10-400$ & 4 & This work \\
\hline
\end{tabular}


rare. Microcrystalline naphthalene has been used as the base for immobilization of some simple organic ligands in preparation of chelating sorbent for solid phase extraction..$^{29-31}$ So it was appropriate to investigate the possibility of preparation of a microcolumn of immobilized stearic acid on microcrystalline naphthalene and to assesses its capability for on-line trace enrichment of metal ions. Studies confirmed the reliability of microcolumn enrichment/separation using stearic acid immobilized on microcrystalline naphthalene, and a rapid method for ultra-trace determination of lead in different samples based on FI-FAAS has been developed.

\section{Experimental}

\section{Instrumentation}

An Instrumentation laboratory AA spectrometer (Buck Scientific Model 210 VGP, USA) furnished with a lead hollow-cathode lamp and air-acetylene flame was used for all measurements. The operating conditions were as follow: wavelength $283.3 \mathrm{~nm}$, slit width $0.7 \mathrm{~nm}$, lamp current 5.1 $\mathrm{mA}$. The absorbance time response was monitored on an $\mathrm{x}-\mathrm{t}$ chard recorder (L-250) and quantitative analysis was based on measurement of the peak height of transient signals. A schematic diagram of flow injection system used is presented in Figure 1. The manifold consists of peristaltic pump (Ismatec, Ms-4 REGLO/8-100 Switzerland), rotary injection valve (Rheodyne, CA, USA) and microcolumn of stearic acid immobilized on microcrystalline naphthalene (PTFE tube $3 \mathrm{~cm} \times 2 \mathrm{~mm}$ i.d.). The FTIR was a Burker, Equinox 55 (Germany).

(a)

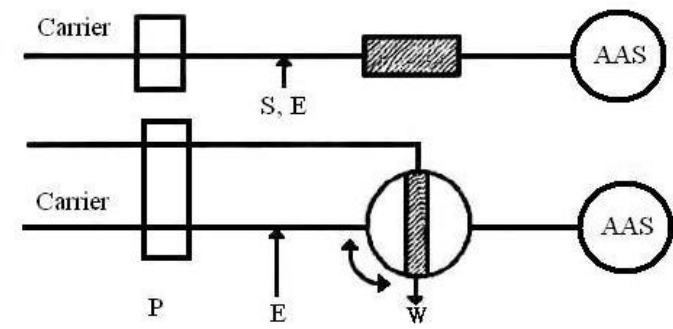

Figure 1. FI manifold for microcolumn preconcentration S, sample; E, eluent; W, waste; P, pump (see Experimental for operating parameter).

\section{Reagents}

All reagents used were of the highest purity available and at least of analytical reagent grade. High purity water was used throughout the sample preparation. Standard solutions were prepared daily by stepwise dilution of 1000 $\mathrm{mg} \mathrm{L} \mathrm{L}^{-1}$ stock solutions (prepared from Titrisol concentrates, Merck). All solutions were stored in precleaned polypropylene (Nalgene) containers.

\section{Preparation of microcolumn}

A solution of naphthalene and stearic acid was prepared by dissolving $1 \mathrm{~g}$ of naphthalene and $0.1 \mathrm{~g}$ of stearic acid in $10 \mathrm{~mL}$ acetone on a hot-plate stirrer at approximately $40{ }^{\circ} \mathrm{C}$. The forementioned solution was added drop wise into $40 \mathrm{~mL}$ of water at room temperature, with continuous stirring. The mixture was stirred for 30 min.; the stearic acid-naphthalene in the form of slurry was used for packing the microcolumn. The microcolumn was fabricated by using PTFE (Teflon) tubing $(3 \mathrm{~cm}$ in length, internal diameter of $2 \mathrm{~mm}$ ) and containing stearic acid immobilized with naphthalene $(\sim 40 \mathrm{mg})$. The end of the tube was fitted with foam to retain the sorbent in the tube.

\section{Preparation of stainless steel sample}

To $0.045 \mathrm{~g}$ of stainless steel, $5 \mathrm{~mL}$ of concentrated hydrochloric acid was added and was heated over water bath for few minutes, $2 \mathrm{~mL} \mathrm{H}_{2} \mathrm{O}_{2}$ solution was added and the heating was continued until the sample was completely dissolved. The solution was diluted with water, $0.2 \mathrm{~g}$ of sodium fluoride was added and the $\mathrm{pH}$ was adjusted to approximately 7 by ammonia solution $\left(0.1 \mathrm{~mol} \mathrm{~L}^{-1}\right)$. The solution was then transferred to $100 \mathrm{~mL}$ flask, and was diluted to mark upon addition of distilled water. The solution was then analyzed according to the given procedure and the result was compared with the accepted value.

\section{Preparation of beet leaf}

To $1.0 \mathrm{~g}$ of dried beet leaf, $4 \mathrm{~mL}$ of concentrated nitric acid was added and the sample was heated on a water bath for $15 \mathrm{~min}$, then $2 \mathrm{~mL}$ of hydrogen peroxide was added and the mixture was heated for another $20 \mathrm{~min}$. The sample was then filtered through a Millipore filter, the $\mathrm{pH}$ was adjusted to $\sim 7$, diluted to the $200 \mathrm{~mL}$, and was treated according to the given procedure.

\section{General procedure}

The flow injection manifold used were as described before $^{32,33}$ and is presented in Figure 1. The single line system (Figure 1a) was used to study analyte breakthrough and to undertake initial method development studies. The two-line FI manifold (Figure 1b) was used to process real samples and to obtain performance data. The carrier and eluent solution were water and nitric acid $(250 \mu \mathrm{L}, 1 \mathrm{~mol}$ $\mathrm{L}^{-1}$ ), respectively. The microcolumn was located in the 
sample loop of injection valve, so the sampling could be performed "off-line" and preventing matrix constituents entering the AAS. At the end of sampling the valve was switch "on-line" and the eluent was injected with the use of second valve to perform elution.

The $\mathrm{pH}$ of solution was adjusted to $\sim 7$ by ammonia solution, with reference to the flow injection manifolds (Figure 1), standard solution or sample were passed through the microcolumn (Figure 1a), sample volume 250 $\mu \mathrm{L}$; Figure $1 \mathrm{~b}$ volume based sampling (e.g. $20 \mathrm{~mL}$ at flow rate of $4 \mathrm{~mL} \mathrm{~min}^{-1}$ ) to perform the sorption of the analyte. Then the retained lead was eluted by injection of nitric acid $\left(250 \mu \mathrm{L}, 1 \mathrm{~mol} \mathrm{~L}^{-1}\right)$ and transported to the flame atomic absorption spectrometer for determination. An injection of $250 \mu \mathrm{L}$ of ammonia solution $\left(0.5 \mathrm{~mol} \mathrm{~L}^{-1}\right)$ was necessary before commencement of the next sorption/ elution cycle to re-establish the column.

\section{Results and Discussion}

It is well known that fatty acids react with some metal ions in a reversible process to form metal carboxylate known as metal soap. In acidic media, these readily dissociate from an ion pair into free metal and free acids. ${ }^{25}$ These facts lead to synthesis of metal carboxylate such as lead stearate which is widely used in industry. We decided to consider the possibility of immobilization of stearic acid in microcrystalline naphthalene, and to assess its potential for on-line adsorption and preconcentration of trace amount of metal ions in a FI system.

It was found that addition of stearic acid to $10 \%$ solution of naphthalene in acetone with continuous stirring causes the stearic acid to coprecipitate with naphthalene in a similar manner already demonstrated for some organic ligands. ${ }^{29-31}$ This was confirmed by characterizing the resulting sorbent using Fourier Transform Infrared Spectrometry (FTIR). The characteristic IR band in $\mathrm{cm}^{-1}$ for immobilized stearic acid were 2916.7 (C-H stretching); 1702 (C=O stretching) and 2400-2800 (OH stretching) which further support the loading of stearic acid on naphthalene. The solid mass in the form of slurry was then used for preparation of microcolumn. Furthermore, in the preliminary study the possibility of preconcentration of metal ions on the immobilized stearic acid was investigated. This was done by processing $50 \mathrm{~mL}$ of a synthetic solution containing $\mathrm{Cu}^{2+}, \mathrm{Pb}^{2+}, \mathrm{Ni}^{2+}, \mathrm{Co}^{2+}$ and $\mathrm{Cd}^{2+}$ at concentration of $4 \mathrm{mg} \mathrm{L}^{-1}$ and at $\mathrm{pH}$ of $\sim 7$ through a glass column loaded with the sorbent at a flow rate of 1

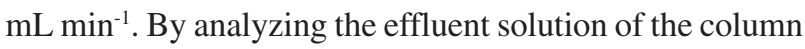
it was found that the column has high affinity for $\mathrm{Pb}^{2+}$ (The percentage of elements adsorbed were 100, 75, 30,
25, and $12 \%$ for $\mathrm{Pb}^{2+}, \mathrm{Cu}^{2+}, \mathrm{Co}^{2+}, \mathrm{Cd}^{2+}$, and $\mathrm{Ni}^{2+}$ respectively). Furthermore with the use of a single line FI system (Figure 1a) it was confirmed, for simple aqueous solution, the lead underwent adsorption/desorption on the immobilized stearic acid microcolumn (for the condition specified under experimental). A typical absorbance time response for the sequential injection of a standard solution (250 $\mu \mathrm{L}$ of $4 \mathrm{mg} \mathrm{L}^{-1}$ lead) and nitric acid $(250 \mathrm{~mL}$ of 1 mol L $\mathrm{L}^{-1}$ ) is given in Figure 2C, and for comparison purpose the equivalent transient signals for direct injection and conventional nebulization of highly acidic $\left(1 \mathrm{~mol} \mathrm{~L}^{-1}\right)$ lead (II) solution are also included (Figure 2B, 2A). From inspection of the peak (Figure 2B) and steady-state responses (Figure 2A) it is evident that the FI modified may be classified as a low dispersion system (dispersion coefficient $=1.1$ ) on the basis that the peak-height response nearly matches the steady-state for conventional nebulization. The dispersion characteristics were modified as a result of column sorption-elution and the relatively narrow and intense elution peak (Figure 2C) signifies a degree of analyte preconcentration (dispersion coefficient $=0.9)$ even though the same volume $(250 \mu \mathrm{L})$ of solution was used in the sorption-elution steps. The result indicates that the analyte was concentrated in a relatively narrow zone of the eluent and that integrity was maintained for AAS detection. The relatively short half-width $(t=6 \mathrm{~s})$ for the elution peak, desirable for the attainment of high sampling rates, was indicative of fast exchange kinetics.

The flow system was optimized by varying the chemical and the flow conditions, in an univariable approach, searching for the best sensitivity to lead. A lead solution containing $200 \mu \mathrm{g} \mathrm{L} \mathrm{L}^{-1}$ was employed for these studies. The effect of the sample $\mathrm{pH}$ on the lead response was investigated. It was found that analyte sorption was dependent on sample $\mathrm{pH}$ and, as shown in Figure 3, high

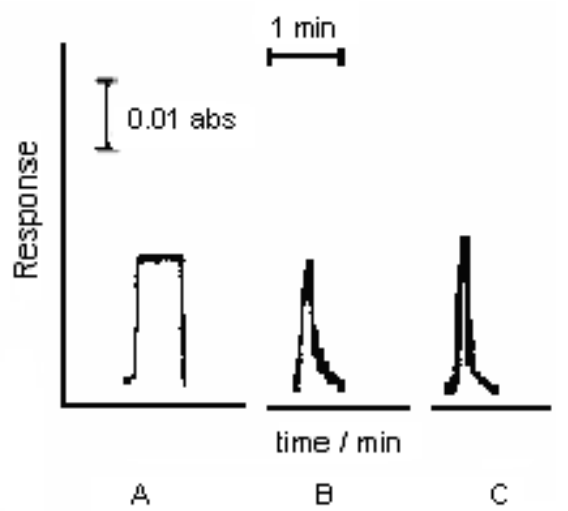

Figure 2. Absorbance versus time, for: (A) sequential injection of $\mathrm{Pb}$ (II) solution $\left(250 \mu \mathrm{L}, 4 \mathrm{mg} \mathrm{L}^{-1} \mathrm{~Pb}, \mathrm{pH} \sim 7\right)$ and nitric acid $\left(250 \mu \mathrm{L}, 1 \mathrm{~mol} \mathrm{~L}^{-1}\right)$; (B) direct injection of highly acidic $\left(1 \mathrm{~mol} \mathrm{~L}^{-1} \mathrm{HNO}_{3}\right) \mathrm{Pb}$ (II) solution $\left(250 \mu \mathrm{L}, 4 \mathrm{mg} \mathrm{L}^{-1} \mathrm{~Pb}\right)$; (C) conventional nebulization of highly acidic $\left(1 \mathrm{~mol} \mathrm{~L}^{-1} \mathrm{HNO}_{3}\right) \mathrm{Pb}(\mathrm{II})$ solution $\left(4 \mathrm{mg} \mathrm{L}^{-1}\right)$. 


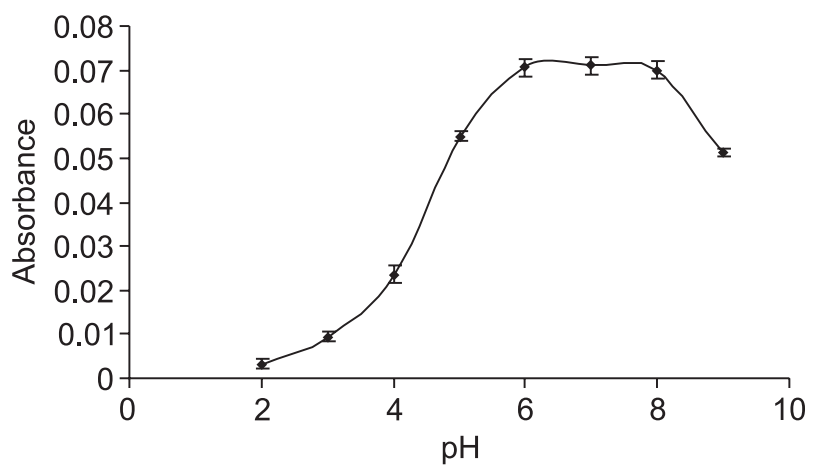

Figure 3. Effect of sample $\mathrm{pH}$ on analyte response. Lead sample, $200 \mu \mathrm{g}$ $\mathrm{L}^{-1}$; sampling volume, $20 \mathrm{~mL}$; eluent nitric acid, $250 \mu \mathrm{L}\left(1 \mathrm{~mol} \mathrm{~L}^{-1}\right)$.

sorption efficiency was achieved at a pH rang of 6-8. Retention of lead decreased progressively at lower or higher $\mathrm{pH}$, as evidenced by an increase in breakthrough signal. This result was expected because at low $\mathrm{pH}$, hydrogen ions compete with lead for adsorption on the microcolumn, and at high $\mathrm{pH}(\mathrm{pH}>8)$ lead may precipitate as lead hydroxide.

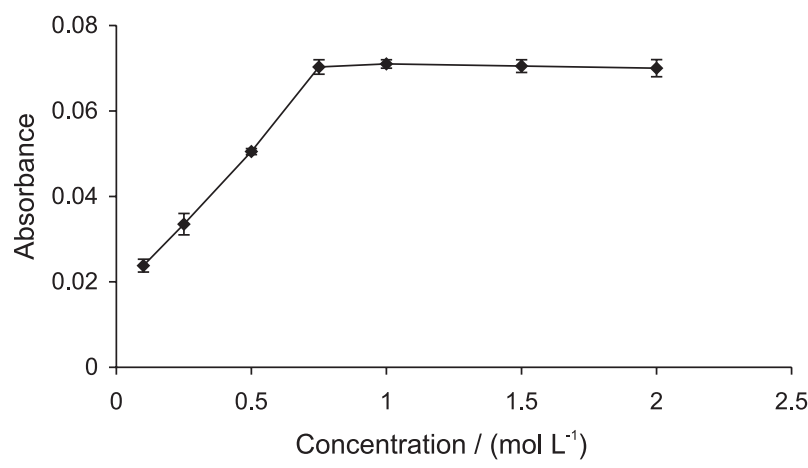

Figure 4. Effect of eluent concentration on deposition of analyte from microcolumn. Lead sample, $200 \mu \mathrm{g} \mathrm{L}^{-1}$; sampling volume, $20 \mathrm{~mL}$; eluent nitric acid, $250 \mu \mathrm{L}$ (varied concentration).

The lead elution from the microcolumn was studied by using nitric acid solutions at different concentration (0.1-2 $\left.\mathrm{mol} \mathrm{L}^{-1}\right)$, as stripping agent. Figure 4 shows that with $250 \mu \mathrm{L}$ eluent, the peak height response was increased with nitric acid concentration up to $0.75 \mathrm{~mol} \mathrm{~L}^{-1}$ and then leveled off at higher concentration; therefore, for subsequent work, nitric acid with a concentration of a 1 mol L $\mathrm{L}^{-1}$ was chosen.

The efficiency of flow rate on analyte sorption on microcolumn was considered by varying the flow rate from 1 to $6 \mathrm{~mL} \mathrm{~min}^{-1}$, while keeping the amount of preconcentrated lead constant at $4 \mu \mathrm{g}$. It was found that the efficiency of analyte deposition was dependent on carrier stream flow rate. For a flow rate up to $4 \mathrm{~mL} \mathrm{~min}^{-1}$ signal response was independent of flow rate. Use of higher flow rate, however resulted in a decrease in signal, suggesting impaired deposition efficiency as a consequence of short

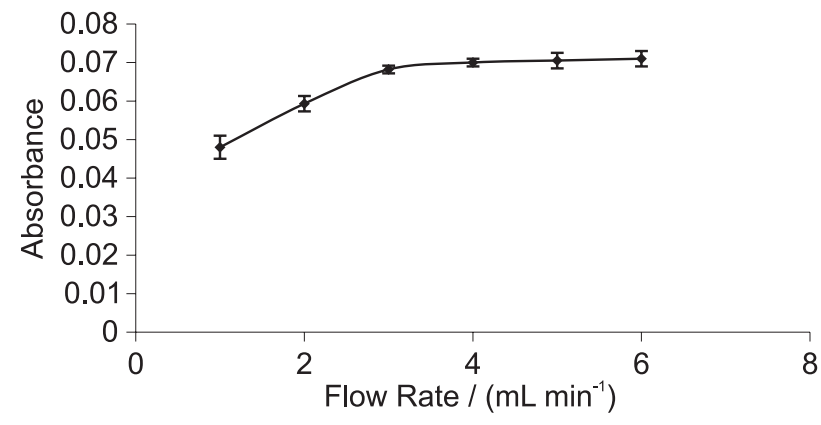

Figure 5. Analyte response for variation of flow rate during elution. Lead sample, $200 \mu \mathrm{g} \mathrm{L}^{-1}$; sampling volume, $20 \mathrm{~mL}$; eluent nitric acid, $250 \mu \mathrm{L}$ (1 $\left.\mathrm{mol} \mathrm{L}^{-1}\right)$.

contact time. The subsequent sampling was performed at

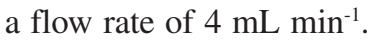

The influence of flow rate of $1 \mathrm{~mol} \mathrm{~L}^{-1}$ nitric acid solution in the step of lead desorption from the microcolumn was also investigated. The result of Figure 5 shows that the analytical signal is maximum and constant at flow rate within the range of 3-6 $\mathrm{mL} \mathrm{min}^{-1}$. At flow rates less than $3 \mathrm{~mL} \mathrm{~min}^{-1}$ the analytical signal considerably decreased, resulting in broader peaks. This is probably, due to incompatibility between the elution and nebulization flow rates, which cause significant dispersion when eluent flow rates is smaller than nebulizer uptake. This experiment also demonstrates that the lead desorption is fast and independent of the elution flow rate. Thus, in the subsequent studies a flow rate of $4 \mathrm{~mL} \mathrm{~min}^{-1}$ was selected to match elution and aspiration flow rates.

The effect of length of the column on efficiency of analyte deposition was considered, and a $3 \mathrm{~cm}$ microcolumn was found to be sufficient. In addition the effect of nature of immobilized fatty acid on extraction of lead was considered, and it was found that the efficiency of extraction varies in the order of stearic acid $\sim$ palmitic acid $>$ oleic acid. It should be noted that palmitic and stearic acid are saturated fatty acids with 16 and 18 carbon atoms respectively where as oleic acid is unsaturated 18 carbon fatty acid.

\section{Analytical performance}

An important aspect of method development was to demonstrate the pre-concentration capability of the FI manifold. The flow system showed good linearity for processing 5-40 $\mathrm{mL}$ of $100 \mu \mathrm{g} \mathrm{L}^{-1} \mathrm{~Pb}$ solutions. The equation of calibration graph was $\mathrm{H}=1.783 \mathrm{~V}-0.141$ (where $\mathrm{H}$ is the peak height and $\mathrm{V}$ is the volume) with correlation coefficient of 0.9991 . A preconcentration factor (based on matching the slope of calibration graph with and without pre-concentration) of 84 with a sampling 
volume of $20 \mathrm{~mL}$ was obtained. This implies a determination capability at the sub $\mu \mathrm{g} \mathrm{L^{-1 }}$.

Twenty and forty milliliters of standard solution were proceed (in triplicate) at a sampling flow rate of $4 \mathrm{~mL}$ $\mathrm{min}^{-1}$ and the graph of absorbance (as peak height) versus lead concentration were linear over the concentration range considered (10-400 $\left.\mu \mathrm{g} \mathrm{L}^{-1}\right)$. The equation of calibration graphs were $\mathrm{H}=0.363 \mathrm{C}+0.629$ and $\mathrm{H}=$ $0.694 \mathrm{C}-0.122$ (where $\mathrm{H}$ is the peak height and $\mathrm{C}$ is the concentration) with correlation coefficient of 0.9992 and 0.9993 , respectively. The calibration slopes increased proportionally with increasing preconcentration volumes, which indicate the retention/elution efficiency of the process is constant $(\sim 100 \%)$.

Furthermore, the deposition efficiency of microcolumn in preconcentration of lead in presence of various cations and anions were examined (Tables 2 and 3 ) and at the given level no significant interference was observed. These results indicated that high concentration of matrix salts have minimal effect on lead species relative to matrix ions. At the $95 \%$ confidence level the relative standard deviation $(\mathrm{n}=6)$ at 40 and $200 \mu \mathrm{g} \mathrm{L}{ }^{-1}$ of lead with $20 \mathrm{~mL}$ of sampling volume were \pm 5.1 and \pm 1.2 , respectively. The limit of

Table 2. Effect of diverse cations on the recovery of lead: lead concentration $100 \mu \mathrm{g} \mathrm{L}^{-1}$; concentrated volume $20 \mathrm{~mL}$; $\mathrm{pH} \sim 7$; flow rate $4 \mathrm{~mL} \mathrm{~min}^{-1}$

\begin{tabular}{lll}
\hline Cation & Mole ratio of $\mathrm{M}^{\mathrm{n}+} / \mathrm{Pb}^{2+}$ & Recovery (\%) \\
\hline $\mathrm{Ca}^{2+}$ & 1000 & 100 \\
$\mathrm{Mg}^{2+}$ & 1000 & 101 \\
$\mathrm{Na}^{+}$ & 1000 & 99 \\
$\mathrm{~K}^{+}$ & 1000 & 100 \\
$\mathrm{Ba}^{2+}$ & 1000 & 103 \\
$\mathrm{Ni}^{2+}$ & 1000 & 100 \\
$\mathrm{Cd}^{2+}$ & 500 & 98 \\
$\mathrm{Mn}^{2+}$ & 500 & 102 \\
$\mathrm{Fe}^{3+}$ & 500 & 99 \\
$\mathrm{Fe}^{2+}$ & 500 & 100 \\
$\mathrm{Cr}^{3+}$ & 100 & 98 \\
$\mathrm{Ag}^{+}$ & 100 & 100 \\
$\mathrm{Co}^{2+}$ & 50 & 97 \\
$\mathrm{Cu}^{2+}$ & 20 & 99 \\
\hline
\end{tabular}

Table 3. Effect of diverse anions on the recovery of lead: lead concentration $100 \mu \mathrm{g} \mathrm{L}^{-1}$; concentrated volume $20 \mathrm{~mL}$; $\mathrm{pH} \sim 7$; flow rate $4 \mathrm{~mL} \mathrm{~min}^{-1}$

\begin{tabular}{lll}
\hline Anion & Mole ratio of $\mathrm{M}^{\mathrm{n}+} / \mathrm{Pb}^{2+}$ & Recovery (\%) \\
\hline $\mathrm{Cl}^{-}$ & 1000 & 97 \\
$\mathrm{Br}$ & 500 & 98 \\
$\mathrm{~F}^{-}$ & 1000 & 99 \\
$\mathrm{CO}_{3}{ }^{2-}$ & 500 & 97 \\
$\mathrm{SO}_{4}^{2-}$ & 1000 & 103 \\
$\mathrm{~S}_{2} \mathrm{O}_{3}^{2-}$ & 1000 & 99 \\
$\mathrm{H}_{2} \mathrm{PO}_{4}^{-}$ & 1000 & 100 \\
$\mathrm{C}_{2} \mathrm{O}_{4}^{2-}$ & 500 & 97 \\
Citrate $^{2-}$ & 10000 & 101 \\
Tartarate & 10000 & 100 \\
\hline
\end{tabular}

detection, based on three times the standard deviation of the blank signal with a sample volume of $40 \mathrm{~mL}$ was found to be $2.9 \mu \mathrm{g} \mathrm{L}^{-1}$ of $\mathrm{Pb}^{2+}$. The breakthrough capacity of immobilized stearic acid microcolumn under the working conditions exceeded $1.58 \mathrm{mg}$ of lead per gram of packing material. This high value suggested high performance of the microcolumn even in the presence of competing ions.

\section{Application}

The FI-AAS procedure was applied to determination of lead in tap water, river water, sea water (taken from Caspian Sea and Persian Golf), apple juice, beet leaf, and urine samples. Reliability was checked by spiking the sample and comparing the results with data obtained, by Graphite Furnace Atomic Absorption Analysis. The results of this investigation are given in Table 4. It can be seen that recovery of spiked sample is good, and there is good agreement between the results and data obtained by Graphite Furnace Atomic Absorption Analysis. Furthermore, the above procedure was applied to the determination of the lead in a certified stainless steel (C12E41 MBH Reference Material with the percentual composition of $\mathrm{C}=0.072, \mathrm{Si}=0.021, \mathrm{~S}=0.323, \mathrm{Mn}=1.09$, $\mathrm{Ni}=0.01, \mathrm{Cr}=0.037 \mathrm{Cu}=0.006$, and $\mathrm{Pb}=0.222$ ). The concentration of lead in the sample were found to be 0.215 $\pm 0.004 \%$ which is in good agreement with the accepted value $(0.222 \%)$; thus the procedure is suitable for the sample type examined.

\section{Conclusions}

It has been demonstrated that long chain fatty acid such as stearic acid immobilized on naphthalene can be used as a sorbent for preconcentration of lead. Furthermore, the proposed FI system incorporating immobilized stearic acid permits effective on-line preconcentration of lead and final determination by FAAS. In addition, it offers an alternative procedure to technique such as GFAAS for determination of lead at $\mu \mathrm{g} \mathrm{L}^{-1}$ level in different matrices. Performance characteristics such as detection limit, capability and precision compare favorably with earlier FI-AAS studies, ${ }^{10-24}$ and have the advantage of tolerance of different matrices. In addition the preparation of sorbent is fairly easy and does not require any chemical reaction.

The main benefits of system were high tolerance to interference ions, enhanced sensitivity of FAAS, low cost, simplicity and speed of analysis. In addition the microcolumn can be used over and over and the sorbent is stable for months. Future work will be directed at the assessment of the suitability of the immobilized microcolumn for the field sampling of lead. 
Table 4. Determination of lead in different samples; concentrated, volume $20 \mathrm{~mL}, \mathrm{pH}$ 7; flow rate, $4 \mathrm{~mL} \min ^{-1}$

\begin{tabular}{|c|c|c|c|c|}
\hline Sample & Added $\left(\mu \mathrm{g} \mathrm{L}^{-1}\right)$ & Found $^{\mathrm{a}}$ & Recovery (\%) & GF-AAS ${ }^{\mathrm{a}}$ \\
\hline \multirow[t]{2}{*}{ Tap water } & - & $<$ LOD & & $3.7 \pm 0.1$ \\
\hline & 40 & $42.1 \pm 1.1$ & 105.2 & \\
\hline Sea water & - & $11.4 \pm 2.2$ & & $11.2 \pm 1.0$ \\
\hline (Caspian) & 40 & $52.1 \pm 1.0$ & 101.7 & \\
\hline Sea water & - & $17.8 \pm 3.0$ & & $18.5 \pm 0.5$ \\
\hline (Persian Golf) & 40 & $57.5 \pm 1.5$ & 99.1 & \\
\hline River water & - & $<$ LOD & & $5.4 \pm 0.02$ \\
\hline (Karoon) & 40 & $41.6 \pm 2.0$ & 104 & \\
\hline \multirow[t]{2}{*}{ Apple juice } & - & $<$ LOD & & $<\mathrm{LOD}$ \\
\hline & 40 & $40.8 \pm 1.4$ & 102 & \\
\hline \multirow[t]{2}{*}{ Beet leaf } & - & $26.0 \pm 1.0$ & & $26.9 \pm 2.0$ \\
\hline & 40 & $63.7 \pm 2.5$ & 94.2 & \\
\hline \multirow[t]{2}{*}{ Urine } & - & $79.5 \pm 1.7$ & & $81.7 \pm 3.2$ \\
\hline & 40 & $121.0 \pm 3.0$ & 103.7 & \\
\hline
\end{tabular}

${ }^{a}$ Average and standard deviation of three determinations.

\section{References}

1. Chisholm, J. J.; Sci. Am. 1971, 224, 15.

2. Terner, D.; Chem. Ber. 1980, 16, 312.

3. Lynarn, D. R.; Plantanido, L.G.; Cole, J. F.; Environmental Lead, Academic press: New York, 1975.

4. Nriagu, J. O.; The Biochemistry of Lead in the Environment, Elsevier: Amsterdam, 1978.

5. Genaro, M. C.; Balocchi, C.; Campi, E.; Mentasti, E.; Argua, R.; Anal. Chim. Acta 1983, 151, 339.

6. de Mora, S. J.; Harrison, R. M.; Anal. Chim. Acta 1983, 153, 307.

7. Reggers, G.; Van Grieken, R.; Fresenius Z. Anal. Chem. 1984, 317, 510.

8. Brajter, K.; Miazek, I.; Fresenius Z. Anal. Chem. 1983, 315 , 121.

9. Fang, Z.; Flow Injection Separation and Pre-concentration, VCH: New York, 1993.

10. Zhang, Y.; Riby, P.; Cox, A. G.; McLeod, C. W.; Date, A. R.; Cheung, Y. Y.; Analyst 1988, 113, 125.

11. Fang, Z.; Guo, T.; Welz, B.; Talanta 1991, 38, 613.

12. Ma, R.; Van Mol, W.; Adams, F.; Anal. Chim. Acta 1994, 285, 33.

13. Lima, R.; Leandro, K. C.; Santelli, R. E.; Talanta 1996, 43, 977.

14. Kartikeyan, S.; Vijayalekshmy, B.; Chandramouleeswaran, S.; Rao, T. P.; Iyer, C. S. P.; Anal. Lett. 1997, 30, 1037.

15. Dadfarnia, S.; Green, I.; McLeod, C. W.; Anal. Proc. 1994, 31, 61.

16. de Pena, Y. P.; Gallego, M.; Valcarcel, M.; Talanta 1995, 42, 211.
17. Zachariadis, Y. P.; Anthemidis, A. N.; Bettas, P. G.; Stratis, J. A.; Talanta 2002, 54, 919.

18. Sooksamiti, P.; Geckeis, H.; Grudpan, K.; Analyst 1996, 121, 1413.

19. Yan, X. P.; Sperling, M.; Welz, B.; Anal. Chem. 1999, 71, 4216.

20. Elsi, L.; Arslan, Z.; Tyson, J. F.; Spectrochim. Acta B 2000, 55, 1109.

21. Quinaia, S. P.; da Silva, J. B. B.; Rollemberg, M. C. E.; Curtius, A. J.; Talanta 2001, 54, 687.

22. Ferreira, S. L. C.; Lemos, V. A.; Santelli, R. E.; Ganzarolli, E.; Curtius, A. J.; Microchem. J. 2001, 68, 41.

23. Lemos, V. A.; Ferreira, S. L. C.; Anal. Chim. Acta 2001, 441, 281.

24. Pereira, M. G.; Arruda, M. A. Z.; Microchim. Acta 2004, 146, 215.

25. Oro, L.; Wertlind, A.; Acta Pharmacol. Toxicol. 1961, $18,141$.

26. Considene, D. M.; Van Nostrand Reinhold Encyclopedia of Chemistry, Van Nostrand Reinhold Company Inc.: USA, 1984.

27. Dadfarnia, S.; Shamsipur, M.; Bull. Chem. Soc. Jpn. 1992, 65, 2779.

28. Akhond M.; Shamsipur, M.; Sep. Sci. Technol. 1997, 32, 1223.

29. Gladis, J. M.; Rao, T. P.; Anal. Lett. 2002, 35, 501.

30. Taher, M. A.; J. Anal. At. Spectrom. 2000, 15, 573.

31. Cai, B.; Hu, B.; Xiong, H.; Liao, Z.; Mao, L.; Jiang, Z.; Talanta 2001, 55,85 .

32. Dadfarnia, S.; Salmanzadeh, A. M.; Haji Shabani, A. M.; J. Anal. At. Spectrom. 2002, 17, 1434.

33. Dadfarnia, S.; Haji Shabani, A. M.; Gohari, M.; Talanta 2004, 64, 682 .

Received: September 29, 2005 Published on the web: April 7, 2006 